\title{
ITABIRITOS E MINÉRIOS DE FERRO DE ALTO TEOR DO QUADRILÁTERO FERRÍFERO - UMA VISÃO GERAL E DISCUSSÃO
}

\author{
Carlos A. Rosière* \& Farid Chemale Jr**
}

\begin{abstract}
Itabirites are Palaeoproterozoic metamorphic banded iron formations from the Itabira Group, Minas Supergroup, that crop out in the Quadrilátero Ferrífero District, Minas Gerais, Brazil. The following compositional types occur: quartz itabirite, being metamorphic jaspilites, dolomitic itabirite, being dolomitized banded iron formations, and amphibolitic itabirite modified by the presence of pelitic sediments. These rocks are also associated to pyritic phyllites and hematitic phyllites. A multiple metamorphic deformational history during two main tectonic events, the Palaeoproterozoic Transamazonian and the Neoproterozoic Brasiliano Event, produced a variety of mineralogical assemblages in the more impure facies and hydrothermal alteration was responsible for carbonatization, intensive oxidation and mineralization. Hypogenic iron mineralization developed in two main phases resulting in thick massive bodies with no relationship to tectonic structures, denominated non-tectonic ores; and schistose ore associated to shear zone, denominated syn-tectonic ores. The mineralizing fluids might be of metamorphic origin, but the importance of hypogenic fluids of magmatic origin is emphasized. Supergene processes on quartz and specially dolomitic itabirites are also of utmost importance in the development of giant ore bodies.
\end{abstract}

\section{INTRODUÇÃO}

Itabiritos, dolomitos ferruginosos e filitos hematíticos compõem um conjunto de formações ferríferas metamórficas do Grupo Itabira na região do Quadrilátero Ferrífero, uma das principais regiões produtoras de minério de ferro do mundo. Metamorfismo e deformação modificaram diversas características primárias dos sedimentos originais e deram a esse conjunto de rochas um aspecto único quando comparados com outras regiões ferríferas. $\mathrm{O}$ entendimento desses processos e seus efeitos nas formações ferríferas permite melhor estabelecer um paralelo entre as rochas que compõem o Grupo Itabira, outras formações ferríferas bandadas de iguais características e jaspilitos anquimetamórficos tais como da Serra dos Carajás, e das Bacias de Transvaal, Hamersley, entre outras. Dessa forma podemos também melhor compreender a evolução geológica da bacia Minas, os processos de mineralização que levaram a gerar grandes corpos de alto teor e, finalmente, estabelecer critérios mais sólidos de pesquisa e prospecção de minério de ferro.

As formações ferríferas do Grupo Itabira sofreram ao longo de sua evolução geológica, além de alterações mineralógicas, intensas modificações texturais entre as quais o desenvolvimento de uma orientação preferencial cristalográfica e morfológica de seus constituintes minerais (Rosière et al. 2001a, no prelo), que dificulta a identificação de estruturas e processos prédeformacionais. A caracterização de minérios pré - e sin-tectônicos e o reconhecimento dos processos mineralizantes é de grande importância econômica não somente para auxiliar nos trabalhos de prospecção e pesquisa como também na caracterização tecnológica. $\mathrm{O}$ ajuste dos parâmetros dos processos metalúrgicos utilizados na aglomeração do minério e produção do ferro metálico depende das características mineralógicas, incluindo o tamanho e arranjo dos cristais que variam dependendo dos processos metalogenéticos envolvidos.

Nesse trabalho fazemos uma revisão das principais características das formações ferríferas do QF enfatizando aspectos mineralógicos e estruturais e texturais acompanhada ainda de uma breve discussão sobre aspectos dos processo metalogenéticos envolvidos na formação dos grandes corpos de alto teor.

\section{GEOLOGIA DO QUADRILÁTERO FERRÍFERO}

O Quadrilátero Ferrífero (Dorr, 1969) está localizado na borda sul do Cráton do São Francisco (Almeida 1977), uma unidade geotectônica de idade Brasiliana cercada por cinturões orogenéticos vergentes para seu interior. O Quadrilátero Ferrífero é caracterizado pelo arranjo grosseiramente quadrangular de sinclinais onde afloram sedimentos plataformais do Supergrupo Minas, de idade Paleoproterozóica, separados por estruturas antiformais irregulares com terrenos arqueanos do tipo greenstone do Supergrupo Nova Lima, e domos de rochas cristalinas Arqueanas e Proterozóicas, (Machado et al. 1992, Machado \& Carneiro 1992, Noce 1995) incluindo granito-gnaisses, metatonalitos a sienogranitos, pegmatitos, anfibolitos, ultramáficas, além de supracrustais metamorfisadas na fácies anfibolito (Fig. 1A). O Supergrupo Minas (Fig. 2) inclui quatro Grupos: Caraça, Itabira, Piracicaba e 
Sabará (Dorr 1969). A seqüência mais espessa de formações ferríferas bandadas com corpos de minério de alto teor economicamente exploráveis pertencem ao Grupo Itabira constituído por itabiritos, dolomitos e, subordinadamente, metapelitos. Itabiritos (Eschwege, 1833) são formações ferríferas metamórficas e fortemente oxidadas apresentando descontinuamente corpos de minério de alto teor $(>64 \% \mathrm{Fe})$, de morfologia mais ou menos lenticular e dimensões variáveis desde alguns decímetros até centenas de metros.

Rochas neoproterozóicas do Supergrupo Espinhaço estão sobrepostas ao Supergrupo Minas em discordância angular com uma seqüência de rift incluindo brechas sedimentares, conglomerados e quartzitos além de rochas metavulcânicas.

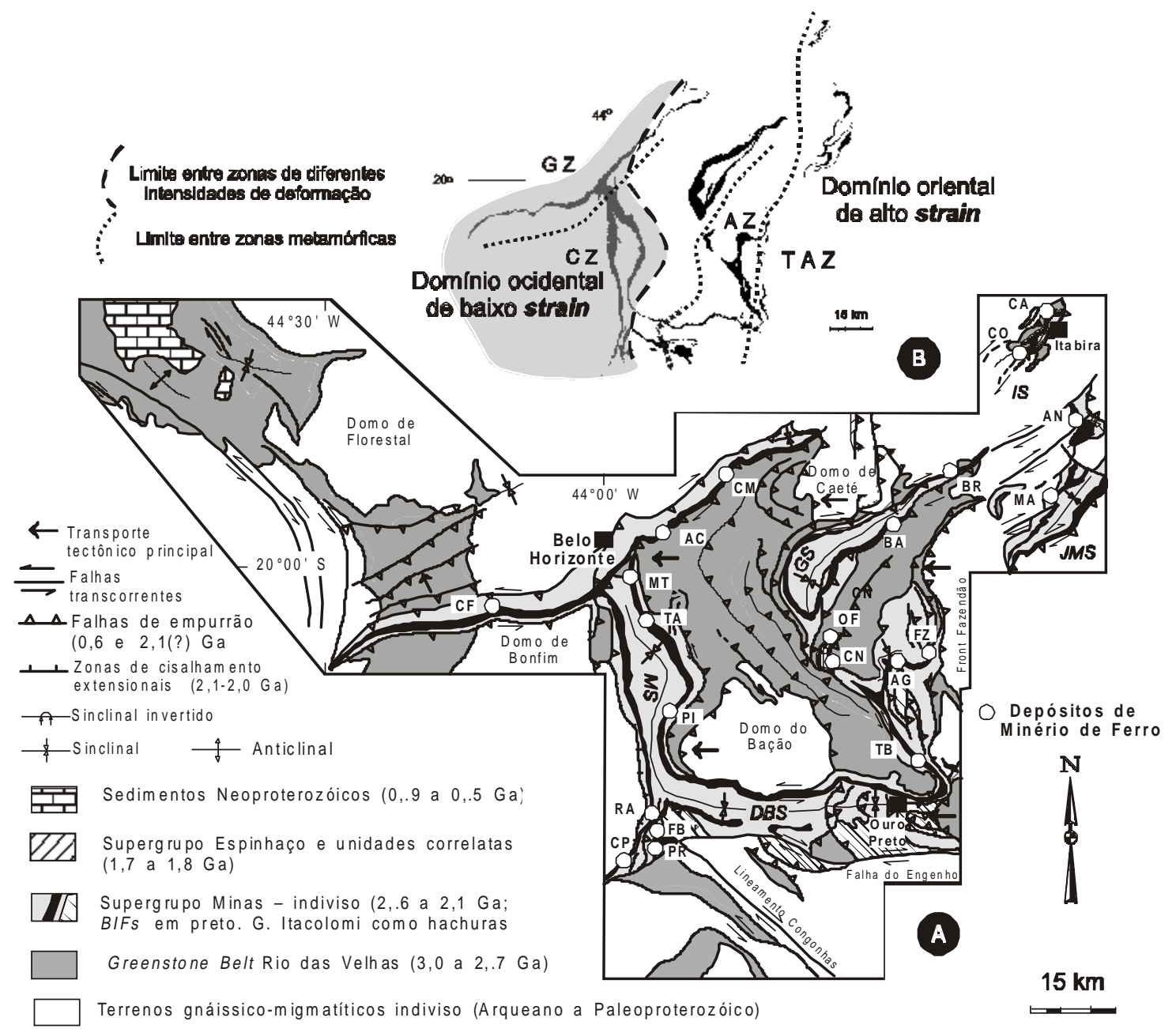

Figura 1: A) Mapa geológico do Quadrilátero Ferrífero (modificado de Baars \& Rosière in Baars, 1997). Principais estruturas tectônicas: DBS - Sinclinal de Dom Bosco, MS - Sinclinal de Moeda, GS - Sinclinal de Gandarela, IS - Sinclinório de Itabira, JMS - Sinclinório de João Monlevade. Principais depósitos de minério de ferro analisados: CF - Córrego do Feijão, MT - Mutuca, TA - Tamanduá, RA - Retiro das Almas, CP - Casa de Pedra, FB - Fábrica, PR - Pires, PI - Pico do Itabirito, AC-Águas Claras, CM - Córrego do Meio, OF Ouro Fino, Capanema, TB - Timbopeba, AG - Alegria, FZ - Fazendão, BA - Baú, BR - Brucutú, MA - Morro Agudo, AN - Andrade, CO - Conceição, CA - Cauê. (B) Localização dos domínios metamórficos e estruturais do Quadrilátero Ferrífero. Área sombreada corresponde a domínio de baixa deformação. Zonas metamórficas segundo Pires (1995): GZ - Zona da Grunerita, CZ - Zona da Cummingtonita, AZ - Zona da Actinolita, TAZ Zona da Tremolita-Antofilita. Representado em preto estão as formações ferríferas do Grupo Itabira.

Figura 1: A) Geologic map of the Quadrilátero Ferrífero (modified after Baars \& Rosière in Baars, 1997). Major tectonic structures : DBS - Dom Bosco Syncline, MS - Moeda Syncline, GS -Gandarela Syncline, IS -Itabira Synclinorium, JMS-Monlevade Synclinorium. Analysed iron orew deposits: CF-Córrego do Feijão, MT-Mutuca, TA - Tamanduá, RA - Retiro das Almas, CP - Casa de Pedra, FB - Fábrica, PR - Pires, PI - Pico do Itabirito, AC Águas Claras, CM - Córrego do Meio, OF - Ouro Fino, Capanema, TB - Timbopeba, AG - Alegria, FZFazendão, BA - Baú, BR - Brucutú, MA - Morro Agudo, AN-Andrade, CO-Conceição, CA - Cauê. (B) Location of metamorphic and structural domains in theQuadrilátero Ferrifero. Shaded area depicts the low strain domain. Metamorphic zones after Pires (1995): GZ-Grunerite Zone, CZ - Cummingtonite Zone, AZ - Actinolite Zone, TAZTremolite-Antophyllite Zone. Depicted in black is the banded iron formation of the Itabira Group. 


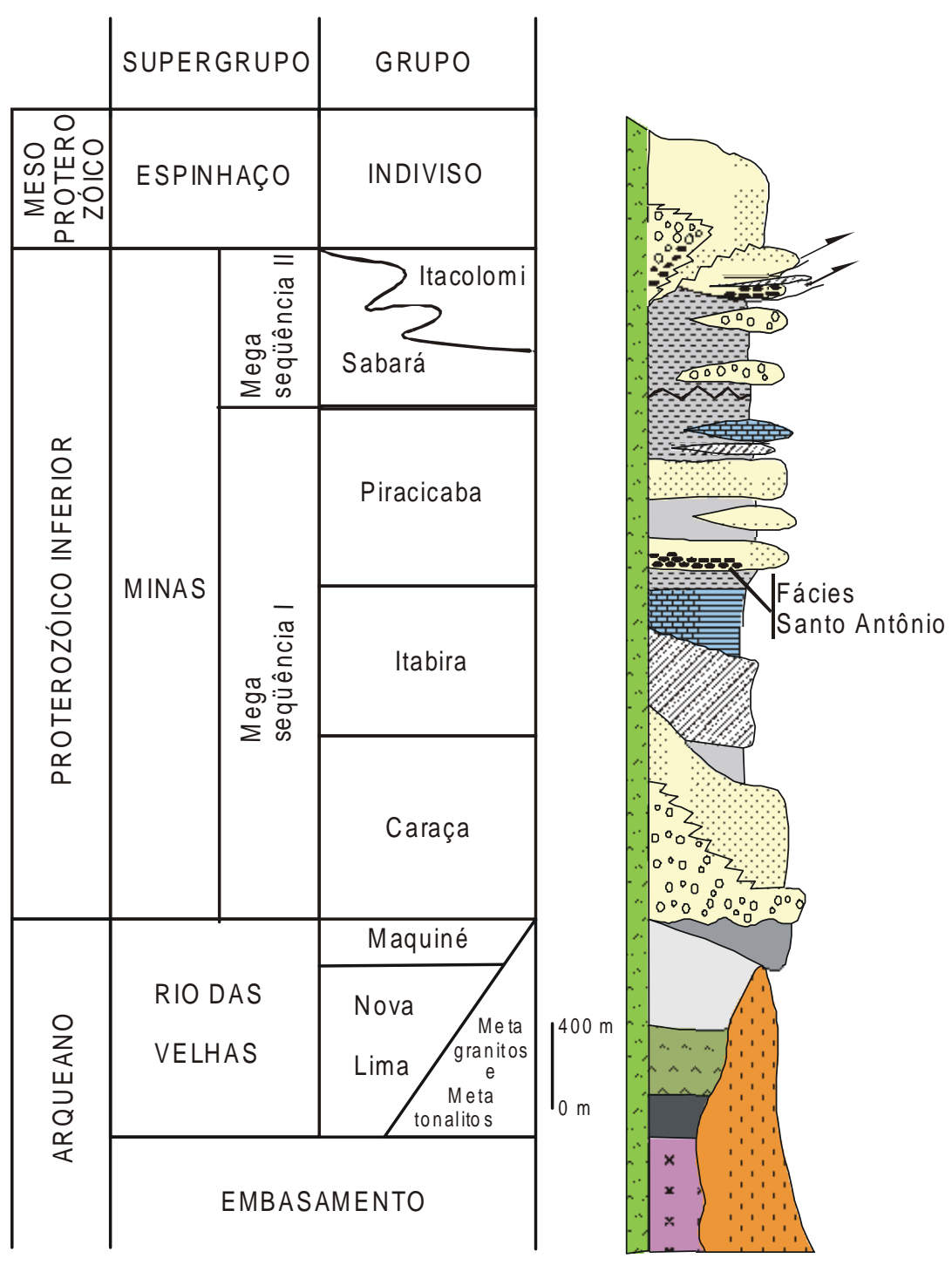

$\lceil\backsim$ Metabásica

\section{臣 Dolomitos e mármores}

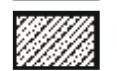

Formação Ferrífera Bandada (FFB)

Metapelitos

$\because$ Quartzitos

Metaconglomerados e brechas

Seixos e fragmentos de formações ferríferas

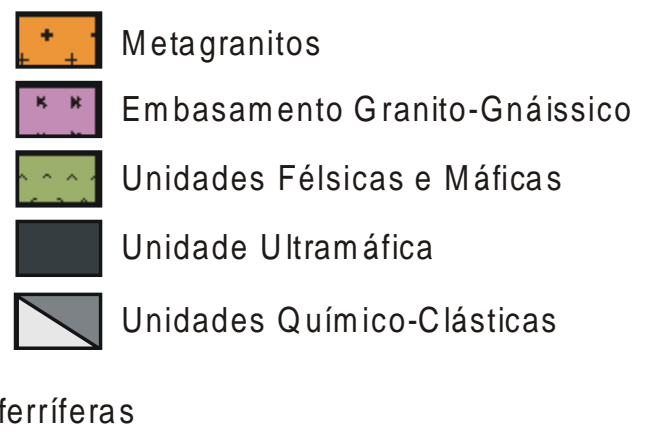

Figura 2: Coluna estratigráfica do Quadrilátero Ferrífero (modificada de Chemale Jr. et al., 1994). Está ressaltado o posicionamento estratigráfico de conglomerados com seixos de itabiritos, em particular a Fácies Santo Antônio segundo Weiss (1990).

Figure 2: Stratigraphy of the Quadrilattero Ferrifero (modified after Chemale Jr. et al., 1994). Depicted is the stratigraphic position of conglomerates with itabirite clasts, particularly the

Santo Antônio Facies after Weiss (1990). 
A estrutura regional é o resultados da superposição de dois eventos deformacionais principais (Chemale Jr. et al. 1994). O primeiro produziu a nucleação de sinclinais regionais nas supracrustais e o soerguimento de domos granito-gnáissicos durante a Orogênese Transamazônica $(2.1$ - 2.0 Ga) resultando em uma estruturação semelhante à encontrada preservada nas bacias de Transvaal e Hamersley. O segundo evento esta relacionado a um cinturão de cavalgamentos vergente para Oeste de idade Pan-Africana/Brasiliana $(0.8-0.6 \mathrm{Ga})$, que provocou inversão, amplificação, translação e rotação dos sinclinais em torno das estruturas dômicas.

Essa evolução tectônica está relacionada a um zonamento metamórfico superposto em auréolas térmicas em torno dos domos (Herz 1978; Marshak et al. 1992) com o crescimento de porfiroblastos de clorita, biotita, granada, cianita, estaurolita, cordierita e silimanita em uma transição de temperaturas baixas a altas. Apesar da interferência dos efeitos de metamorfismo nas auréolas circun-dômicas que provocam "saltos" metamórficos significativos mas de importância local, é possível estabelecer isógradas regionais para o Quadrilátero Ferrífero. Herz (1978) definiu três zonas principais (clorita, biotita e estaurolita) com temperaturas de equilíbrio crescentes para leste e que variam entre aprox. 300 e $600^{\circ} \mathrm{C}$. Hoefs et al. (1982), baseados em isótopos de $\mathrm{O}$ de quartzo e hematita dos itabiritos da Formação Cauê, também sugerem um aumento do metamorfismo para leste. Pires (1995) redefiniu essas isógradas para rochas pelíticas e formações ferríferas do Grupo Itabira como apresentado na Fig. 1B. O zonamento metamórfico é acompanhado por um gradiente deformacional de modo que é possível separar o Quadrilátero Ferrífero em dois domínios estruturais principais (Rosière et al. 2001a, no prelo) (Fig. 1B):

- domínio de baixa deformação (DBD), que cobre principalmente as zonas metamórficas da grunerita (GZ) and cummingtonita (CZ) (Pires 1995) com megassinclinais bem preservados como principais estruturas regionais. Zonas de cisalhamento descontinuas e falhas de cavalgamento relacionadas ao segundo evento tectônico intersectam as estruturas megascópicas. Nos itabiritos estão preservadas diversas estruturas de origem sedimentar e diagenética tais como o meso - e microbandamento, pods formados por compactação diferencial e pisólitos (Beukes 1980).

- domínio oriental de alta deformação (DAD), que cobre principalmente as zonas metamórficas da actinolita (AZ) e da tremolita - antofilita (TAZ) (Pires 1995) e é dominada por cavalgamentos e zonas transcorrentes (Rosière et al. 1997). gerando dobras apertadas a isoclinais e espessas zonas de milonitização (Chemale Jr. et al. 1994). Evidências de retrometamorfismo de ocorrência descontínua estão aparentemente associadas às fases finais da tectônica compressiva.

Granitos foram gerados em duas fases distintas relacionadas às duas fases orogenéticas. A primeira granitogênese, Transamazônica, desenvolveu-se de forma modesta dentro do QF sendo os efeitos de metamorfismo térmico (facies anfibolito) na região, de idade entre 2.04 e $2.06 \mathrm{Ga}$ associados à fusão parcial do embasamento Arqueano e geração de pegmatitos (Machado et al. 1992, Noce 1995). Plutons granitóides Transamazônicos de idades 2.62 - 2.48; 2.43 e 2.27 2.30 (Noce et al. 2000) são encontrados principalmente ao sul da Falha do Engenho, sendo provavelmente alguns deles com elevado grau de aloctonia (Chemale Jr. et al. 1994).

$\mathrm{Na}$ parte leste do Quadrilátero ocorrem ainda metagranitos caracterizados genericamente como do tipo Borrachudo, de origem crustal, com idades U-Pb de 1.670 +/- 32 Ma para zircões e 1.351+/-6 Ma para titanitas sintectônicas e idade modelo $\mathrm{T}_{\mathrm{DM}}=3.72 \mathrm{Ga}$ (Chemale Jr. et al. 1997), obtida a partir de dados Sm$\mathrm{Nd}$ de rocha total. Essas idades sugerem que tais granitos são originados de fusão da crosta inferior Arqueana, cristalizados durante o magmatismo sin-rifteamento da bacia Espinhaço e metamorfisados sintectônicamente durante o Neoproterozóico provavelmente numa fase precoce do ciclo Brasiliano (Chemale Jr. et al. 1997).

\section{O GRUPO ITABIRA - POSIÇÃO ESTRATIGRÁFICA E AMBIENTE DE SEDIMENTAÇÃO}

A estratigrafia do Supergrupo Minas pode ser dividida em duas megaseqüências principais: (I) uma sequiência entre fluvial deltaica e marinha plataformal que inclui os Grupos Caraça, Itabira e Piracicaba e (II), depósitos marinhos imaturos do Grupo Sabará (Fig. 2).

O Grupo Itabira, onde estão os itabiritos, é uma seqüência predominantemente marinha de ambiente raso a profundo, depositada sobre a seqüência clástica progradante do Grupo Caraça ( 2600 Ma a $2520 \mathrm{Ma}$ Romano 1989, Renger et al. 1994, Noce, 1995; Machado et al. 1996,) que apresenta, da base para o topo, conglomerados, quartzitos e metapelitos. A fase marinha iniciou-se com os filitos carbonosos, sericitafilitos e filitos dolomíticos que passam lateralmente e para o topo, de forma gradativa, a hematita - filitos, itabiritos e dolomitos. Renger et al. (1994) propõem para o limite superior do Grupo Caraça o aparecimento de filitos carbonáticos interpretando-os como início da sedimentação química, e representam, conseqüentemente, uma mudança nas condições de sedimentação da bacia, de modo a permitir a deposição da seção inferior do Grupo Itabira.

Embora o Grupo Itabira seja dividido em uma unidade inferior, a Formação Cauê onde predominam itabiritos e uma superior, a Formação Gandarela com rochas carbonáticas (dolomitos e mármores dolomíticos e calcíticos), filitos e formações ferríferas bandadas, não existe uma nítida separação entre elas. Ao invés disso dolomitos e itabiritos ocorrem intercalados tanto vertical como lateralmente (Pires 1995) e o contato entre as litologias é freqüentemente brusco. Na Formação 
Cauê ocorrem as formações ferríferas mais espessas do Supergrupo Minas (200 - 300m), os itabiritos, juntamente com hematita - filitos, filitos dolomíticos e mármores. Babinski et al. (1995) dataram carbonatos estromatolíticos da Formação Gandarela como 2419 +/- $19 \mathrm{Ma}(\mathrm{Pb}-\mathrm{Pb})$ e, considerando taxas de deposição de aprox. $3 \mathrm{~m} / \mathrm{Ma}$ como postulado por Trendall et al. (1990) para a seqüência de formações ferríferas da bacia de Hamersley a Formação Cauê, sobrejacente, e de espessura média de $300 \mathrm{~m}$ deduziram ter a deposição ocorrido entre 2520 and 2420 Ma.

Superposto ao Grupo Itabira está o Grupo Piracicaba que, em sua porção basal apresenta comumente feições turbidíticas com metarenitos, geralmente ferruginosos, intercalados com filitos. Essa seqüência passa na lateral e vertical para filitos carbonáticos, filitos ferruginosos assim como dolomitos, mármores estromatolíticos e formações ferríferas bandadas. A complexa variação lateral e vertical de fácies desenvolveu-se pela alternância de condições transgressivas.

O registro litológico da megaseqüência I do Supergrupo Minas que inclui os grupos Caraça, Itabira e Piracicaba é interpretado por Chemale Jr. et al. (1994) como sendo depositado em uma bacia intracratônica enquanto Alkmim \& Marshak (1998) interpretam como margem passiva. A ausência de indicadores de um ambiente tectônicamente instável tais como vulcanismo intenso, estruturas indicativas de sedimentação sinorogênica ou a presença de sedimentos imaturos não suportam qualquer modelo envolvendo ambiente orogenético como uma bacia do tipoforeland da forma preconizada por Hoffman (1987) para a bacia de Animikie no Escudo Canadense..

Separada das unidade inferiores por uma discordância regional ocorre a megasequiência II do Grupo Sabará caracterizada por um depósito orogênico Paleoproterozóico (Transamazônico $2.10-2.0 \mathrm{Ga}$ ) (Renger et al., 1994, Alkmim \& Marshak 1998) com características de flysch compreendendo metagrauvacas, metadiamictitos, tufos e metavulcanitos ácidos a intermediários associados a filitos carbonosos e formações ferríferas bandadas, depositado 300Ma após a sedimentação das rochas do grupo Itabira em ambiente plataformal. Machado et al. (1992) dataram zircões (U/ $\mathrm{Pb}$ ) provenientes de tufos dessa unidade obtendo idade de $2.125 \mathrm{Ga}$ que interpretam como sendo de sua deposição. Quartzitos, quartzitos arcosianos e arcósios do Grupo Itacolomi recobrem a seqüência e correspondem a sedimentos de bacia molássica dessa orogênese, de idade semelhante do Grupo Sabará.

\section{AS FORMAÇÕES FERRÍFERAS DO GRUPO ITABIRA}

Os seguintes tipos de formações ferríferas podem ser reconhecidos no Quadrilátero Ferrífero: itabiritos, hematita filitos, $\mathrm{Fe}$ - dolomitos e, subordinadamente, filitos piritosos (Tabela 1). Itabiritos são formações ferríferas bandadas metamórficas, deformadas e oxidadas de modo que sua classificação como fácies óxido é muito distante do sentido dado por James (1954) que era baseado em critérios essencialmente sedimentares. Hematita filitos ocorrem como lentes constituídas de sericita (+/- clorita) e hematita na base da Formação Cauê, no contato com a Formação Batatal. Localmente ocorrem lentes de hematita compacta intercaladas. Filitos piritosos são filitos carbonosos com níveis e lentes ricas em sulfetos de espessura milimétrica (Fig. 3e). Elas tem ocorrência restrita como, por exemplo, na Mina de Águas Claras, Serra do Curral (Fig. 1).

Na maioria das bacias ferríferas tais como a de Animikie (região do Lago Superior), Hamersley (Austrália) e Transvaal (África do Sul), onde o grau metamórfico é predominantemente baixo (Morey, 1983, Trendall \& Blockley, 1970, Trendall 1983, Button 1986, Beukes 1986), a variação mineralógica das formações ferríferas é grande com a presença de sílica, carbonatos

\begin{tabular}{|l|l|l|}
\hline $\begin{array}{c}\text { TIPOS DE } \\
\text { FORMAÇÃO } \\
\text { FERRÍFERA }\end{array}$ & \multicolumn{1}{|c|}{$\begin{array}{c}\text { COMPONENTES MINERALÓGICOS } \\
\text { PRINCIPAIS }\end{array}$} & COMPONENTES ACESSÓRIOS \\
\hline Itabirito comum & $\begin{array}{l}\text { Hematita, martita, kenomagnetita, } \\
\text { quartzo }\end{array}$ & $\begin{array}{l}\text { Clorita, sericita, dolomita ferroana, caolinita, } \\
\text { cianita, Óxidos de Mn, sulfetos, apatita, pirofilita }\end{array}$ \\
\hline Itabirito dolomítico & $\begin{array}{l}\text { Martita, hematita, kenomagnetita, } \\
\text { dolomita ferroana }\end{array}$ & $\begin{array}{l}\text { Calcita, grunerita-cummingtonita, clorita, } \\
\text { stilpnomelana, biotita, tremolita, actinolita, } \\
\text { quartzo (chert), sulfetos, pirofilita }\end{array}$ \\
\hline $\begin{array}{l}\text { Itabirito } \\
\text { anfibolítico }\end{array}$ & $\begin{array}{l}\text { Martita, hematita, kenomagnetita, } \\
\text { maghemita, grunerita- } \\
\text { cummingtonita, tremolita, } \\
\text { actinolita, quartzo. }\end{array}$ & $\begin{array}{l}\text { carbonato, talco, dolomita ferroana, egina, } \\
\text { biotita, Mg-riebeckita, kupferita, sulfetos }\end{array}$ \\
\hline Hematita - filito & Hematita, sericita & quartzo, clorita \\
\hline Filito piritoso & Pirita, matéria carbonosa & \\
\hline
\end{tabular}

Tabela 1: Mineralogia dos diferentes tipos composicionais de formações ferríferas (inclui dados de Pires, 1995). Table 1: Mineralogy of different composition types of iron formations. 
e silicatos de ferro de origem diagenética (Simonson 1987) além de componentes aloquímicos tais como oolitos, shards etc (Beukes 1980). Somente na proximidade de zonas mineralizadas observa-se uma intensa oxidação cuja origem, supergênica ou hidrotermal, tem sido extensivamente discutida na literatura (Morris 1980, Barley et. al. 1999, entre outros). Diferentemente do que ocorre nas outras bacias, a seqüência de itabiritos no Quadrilátero Ferrífero é relativamente monótona, sendo hematita o óxido predominante sob diferentes formas (martita, hematita granoblástica e especularita) geradas em diferentes gerações e com clara relação com o grau de metamorfismo e deformação (Rosière et al. 2001a, no prelo). Magnetita ocorre na maioria das vezes sob a forma de kenomagnetita (Kullerud et al. 1969) como cristais idiomórficos a hipidiomórficos individualmente ou constituindo agregados. Frequientemente ocorrem como relictos dentro dos cristais de hematita. Quartzo é o mineral de ganga predominante, além de dolomita e anfibólios (grunerita, tremolita, actinolita, cummingtonita, antofilita) que permitem a definição dos três tipos composicionais principais: quartzo-itabirito, itabirito dolomítico e itabirito anfibolítico (Tabela 1). Outros silicatos ocorrem como acessórios mais ou menos raramente tais como filossilicatos (sericita, clorita, muscovita), além de cianita, talco, pirofilita, granada, estaurolita), biotita, apatita, caolinita, cloritóide, fuchsita, flogopita, crisotila, stilpnomelana, titanita e apatita (ver Pires 1995 para uma petrografia detalhada; Guba 1982, Rosière 1981). Por outro lado as estruturas tectônicas resultaram em uma rica variedade de características texturais em função do desenvolvimento das plaquetas de especularita (Rosière et al. 2001a, no prelo) cuja distribuição caracteriza clivagens de tipos e morfologia variada e define tipos tectônicos (Tabela 2) com diferentes tramas e microestruturas.
A distribuição dos diferentes tipos de itabirito não pode ser representada em um modelo de "bolo de camadas" que negligencia a complexa interdigitação entre elas. A distribuição dos diferentes tipos composicionais esta condicionado por três fatores:

Composição original dos sedimentos na bacia - em virtude da influência dos processos secundários (metamorfismo, alteração hidrotermal, deformação etc.) é difícil avaliar a real distribuição de sedimentos na bacia. A presença das variedades anfibolíticas (Fig 3d) é certamente condicionada pela presença de material terrígeno (formações ferríferas argilosas) e existe uma diminuição progressiva no aporte de Fe na bacia associado à diminuição de espessura da lâmina de água e o desenvolvimento de uma plataforma carbonática (Formação Gandarela).

Estruturação tectônica - o contraste no comportamento reológico das formações ferríferas (Rosière et al. 2001a, no prelo) em relação aos psamitos sobre e subjacentes (Grupo Caraça e Grupo Piracicaba, respectivamente) resultou em uma complexa estruturação interna nas formações ferríferas com superposição de dobras e desenvolvimento de zonas de cisalhamento obliterando ao mesmo tempo diversas característica sedimentares e diagenéticas. Através da deformação e metamorfismo desenvolvem-se diversas transformações texturais formando ferro-tectonitos.

Metamorfismo e processos hidrotermais - Os efeitos do metamorfismo em formações ferríferas bandadas resulta em transformações mineralógicas que são notáveis nas fácies mais impuras, com o aumento de componentes terrígenos tais como a cristalização de anfibólios, clorita, etc. A presença de fluidos hidrotermais, entretanto pode provocar grandes modificações na composição original, de forma que suas características "primárias" podem ser parcial ou totalmente obliteradas. No Quadrilátero Ferrífero os itabiritos sofreram, além das reações metamórficas que

\begin{tabular}{|l|l|}
\hline TIPOS TECTÔNICOS* & \multicolumn{1}{|c|}{ CARACTERÍSTICAS PRINCIPAIS } \\
\hline $\begin{array}{l}\text { Itabiritos e minérios } \\
\text { xistosos }\end{array}$ & $\begin{array}{l}\text { Trama fortemente orientada, protomilonítica a milonítica com porfiroclastos de } \\
\text { martita e agregados de hematita granoblástica envolvidos por plaquetas de } \\
\text { especularita. Cristais de anfibólio orientados. Transposição parcial ou total do } \\
\text { bandamento primário. Dobras sem raízes. Carbonatos e quartzo apresentam trama } \\
\text { granoblástica }\end{array}$ \\
\hline Brechas & $\begin{array}{l}\text { Fragmentos não orientados de itabirito e minério compacto em matriz constituída de } \\
\text { quartzo sacaroidal, carbonato ou hematita } \\
\text { Fragmentos não orientados de itabirito bandado e hematita compacta em matriz de } \\
\text { quartzo sacaroidal, carbonatos ou hematita. }\end{array}$ \\
\hline Cataclasitos (Blue & $\begin{array}{l}\text { Finos cristais de especularita apresentando fraca ou nenhuma orientação } \\
\text { preferencial. Evidências de hidrotermalismo. Mineralização de ouro associada. }\end{array}$ \\
\hline dust $)$ & \\
\hline
\end{tabular}

*Hematita é a fase dominante em todos os tipos.

Tabela 2. Características principais dos tipos tectônicos.

Table 2: Main features of tectonic types. 

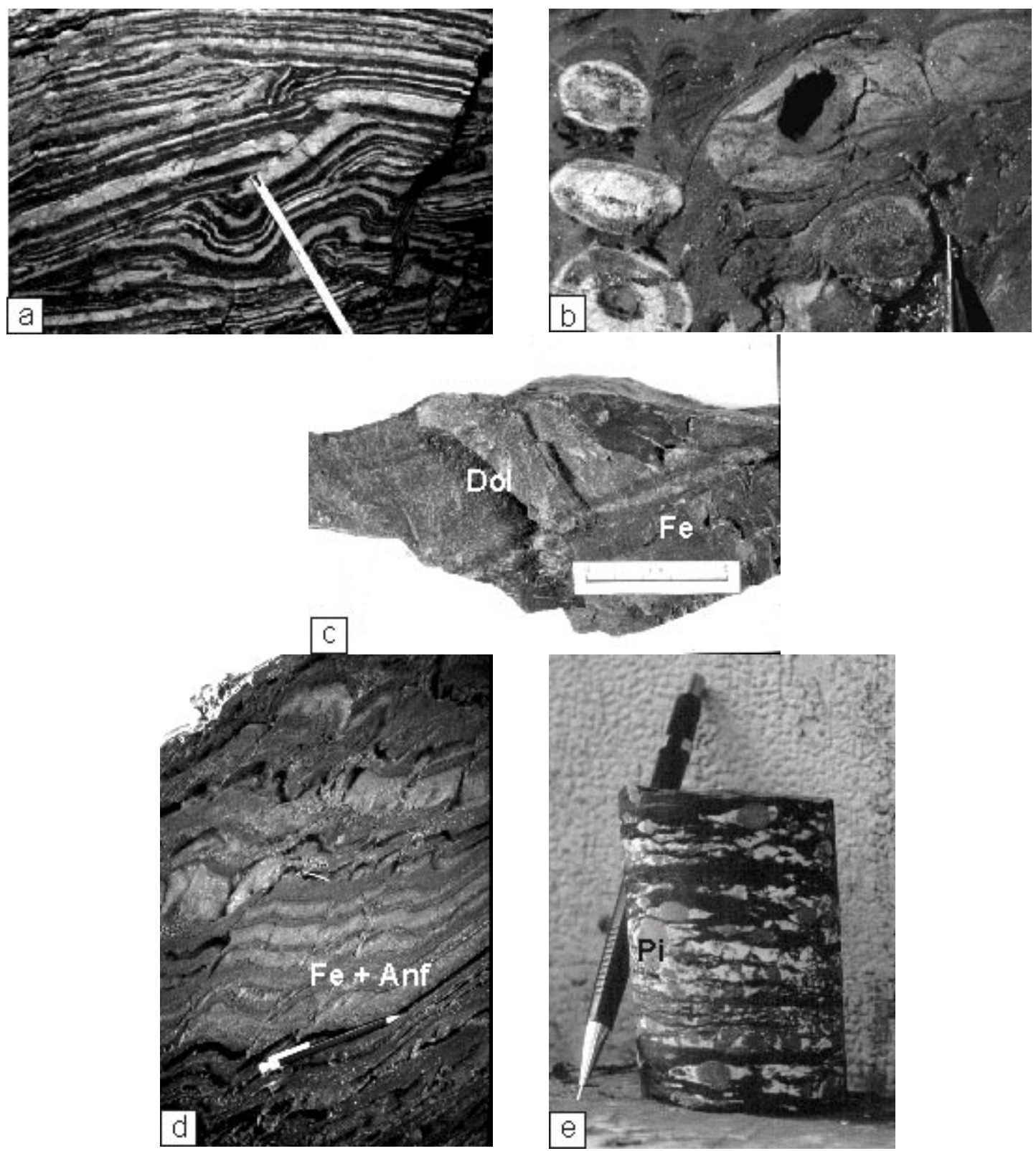

Figura 3: Diferentes tipos de formações ferriferas do Quadrilátero Ferrífero. a. Quartzo itabirito apresentando dobras parasíticas paralelas concêntricas ou quase concêntricas e pequenos cavalgamentos internos. As estruturas são típicas de condições dúcteis rúpteis. Mina do Pico. A escala na foto corresponde a aprox. $20 \mathrm{~cm}$. $b$. Estruturas pisolíticas primárias deformadas em itabirito. Os pisólitos apresentam bandamento interno e estrutura concêntrica. Retiro das Pedras. c. Itabirito dolomítico com bandamento grosseiro definido pela alternância de níveis de óxidos de ferro - magnetita e martita $(\mathrm{Fe})$ e dolomita ferroana (Dol). Mina de Águas Claras. d. Itabirito anfibolítico dobrados. O bandamento é definido por níveis escuros (Fe + Anf) constituídos de óxidos de ferro (predominantemente magnetita) e goethita pseudomórfica em cristais de anfibólio e níveis mais claros constituídos de quartzo com anfibólio disseminado. Mina de Capanema. e. Filito carbonoso com pirita (Pi) esferoidal (origem orgânica?). Os cristais de pirita apresentam-se parcialmente cataclasados e com sombras de pressão. Mina de Äguas Claras.

Figure 3: Different types of iron formations of the Quadrilátero Ferrifero. a. Quartz- itabirite with nearconcentric, parallel folds and small thrust faults. Structures were developed under ductile-brittle conditions. Pico Mine. Scale on photo is approx. 20cm long. b. Deformed pisolites in itabirite. They present relictic internal banding and concentric structure. Retiro das Pedras. c. Dolomitic itabirite with bandamento grosseiro defined by alternating levels of iron oxides - magnetite and martite $(\mathrm{Fe})$ and ferroan dolomite (Dol). Águas Claras Mine. d. Folded amphibolitic itabirite. Banding is defined by dark layers ( $\mathrm{Fe}+\mathrm{Anf}$ ) of iron oxides (mainly magnetite) and goethite pseudomorphic in amphiboles and light layers of quartz and disseminated amphiboles. Capanema Mine. e. Carbon-rich phyllite with pyrite spheroids (Pi) (organic?). Pyrite crystals are in partially cataclastic deformed with pressure shadows. Águas Claras Mine. 
se refletem principalmente nas associações mineralógicas dos silicatos, um intenso processo de oxidação e alteração hidrotermal. Isso se pode verificar através da análise petrográfica comparativa das características mineralógicas de amostras provenientes de diferentes domínios estruturais e metamórficos (Pires, 1995, Rosière et al. 2001a, no prelo) sendo as principais:

- progressiva martitização da magnetita (Rosière 1981), - a presença de cristais de hematita de habitus e morfologia atípica, caracterizando pseudomorfismo provavelmente em silicatos (Fig. 5c).

- evidência de dolomitização de quartzo - itabiritos e transformação da dolomita em hematita (Fig. 4d).

- evidência de talcificação.

- Microestruturas indicativas de mobilização sintectônica de Fe (Lagoeiro, 1998)

- Existência de inclusões fluidas na hematita (Rosière et al. 2001b, no prelo)

- Existência de veios de hematita cortando o bandamento

\section{Tipos composicionais}

Quarzo itabirito representa o tipo mais comum encontrado no Quadrilátero Ferrífero. Corresponde a jaspilitos metamórficos apresentando alternância de níveis claros (quartzo) e escuros (óxidos de ferro) de espessura milimétrica a centimétrica (Fig 3a) comumente reproduzindo o microbandamento característico como definido por Trendall $(1973,1983)$ além de diversas estruturas tais comopods e ondulações, interpretadas nas rochas anquimetamórficas como produto de diagênese e compactação diferencial. Quartzo ocorre geralmente como cristais equidimensionais, resultado da recristalização de chert dos jaspilitos. Veios de quartzo sacaroidal são comuns tanto concordantes como discordantes em relação ao bandamento, seja ele tectônico ou primário.

Itabiritos dolomíticos são constituídos de bandas de dolomita ferroana, quartzo, óxidos de ferro (Fig 3c) podendo apresentar calcita, clorita e anfibólios. Esse tipo grada para dolomitos ferruginosos com bandas claras de carbonato e escuras de óxidos de ferro que devem igualmente ser consideradas como formações ferríferas dolomíticas.

Itabiritos anfibolíticos (Fig. 3d) apresentam sempre anfibólios de composição variada como cristais idiomórficos a hipidiomórficos, sem orientação ou constituindo uma trama granolepidoblástica a lepidoblástica de cristais orientados segundo o bandamento (Fig. 5e) ou na xistosidade plano-axial e definindo também uma lineação mineral.

\section{Tipos tectônicos}

Os principais tipos tectônicos de itabiritos podem ser caracterizados como Fe-tectonitos constituindo protomilonitos e milonitos, descritos geralmente como itabiritos xistosos (Tabela 2). Essas rochas apresentam uma foliação bem desenvolvida, minerais estirados e outras estruturas típicas de tectonitos tais como sombras de pressão, lamelas de geminação mecânica, bandas de cisalhamento, boudins, boudins de foliação. No DBD, na porção oeste do Quadrilátero Ferrífero, Fe tectonitos ocorrem de forma descontínua, em zonas de cisalhamento discretas, tornando-se mais comuns e espessos a leste, no DAD, até aparecer como a litologia predominante no extremo leste e nordeste da região.

$\mathrm{Em} \mathrm{Fe}$ - tectonitos, hematita cresce na forma de palhetas denominadas de especularita com orientação preferencial cristalográfica e de forma do grão caracterizando uma textura que pode ser próxima a de monocristal. Silicatos orientados podem estar presentes como cianita, anfibólios, filossilicatos. Nas sombras de pressão desenvolvem-se também além da especularita, cristais elongados de quartzo.

Especularita está diretamente associada à intensidade da deformação em condições dúcteis formando foliações de morfologia variável, desde do tipo espaçado até o tipo contínuo, com total transposição da estruturação "primária", herdada dos jaspilitos, produzindo um bandamento tectono-metamórfico de morfologia regular, com a presença de dobras intrafoliais, isoclinais, sem raiz.

Em falhas e zonas de cisalhamento rúpteis desenvolvem-se brechas e cataclasitos. Brechas são constituídas de fragmentos de hematita compacta ou itabirito em matriz de quartzo, carbonato ou hematita. Brechas ocorrem geralmente como bolsões descontínuos distribuídos irregularmente. Alguns estão claramente associados à falhas tectônicas embora outras parecem ser produto de fraturamento hidráulico (Fig 4c). Em ambos os casos, entretanto uma sobrepressão de fluido teve papel importante no comportamento rúptil das formações ferríferas do Grupo Itabira levando à cataclase de seus componentes, em particular da magnetita (Rosière et al., 2001a, no prelo). Cataclasitos são constituídos essencialmente de pó de hematita e alguns fragmentos de maior dimensão com cristais de hematita muito deformados apresentando lamelas de geminação mecânica. A hematita da matriz é comumente lamelar e a presença de talco, caolim, óxido de manganês além de acessórios como turmalina, epidoto juntamente com eventual mineralização de ouro (Olivo et al. 1995, Galbiatti 1999) são indicativos de alteração hidrotermal associada. Esses tectonitos rúpteis dão origem ao minério conhecido como blue dust.

\section{MINÉRIOS DE FERRO DE ALTO TEOR}

Corpos de minério rico são caracterizados por teores em $\mathrm{Fe}>64 \%$ praticamente sem $\mathrm{SiO}_{2}, \mathrm{Al}_{2} \mathrm{O}_{3}, \mathrm{P}$, álcalis etc. Sua origem é motivo de controvérsias desde o trabalho de Leith (1903) sendo os seguintes pontos, principais focos de discussão:

- Origem singenética vs. epigenética

- Origem das soluções mineralizantes nos modelos epigenéticos

- Processos envolvidos na mineralização

- Idade relativa da mineralização dentro da história geológica da bacia

A existência de corpos singenéticos, na forma de lentes hematíticas dentro das formações ferríferas parece 

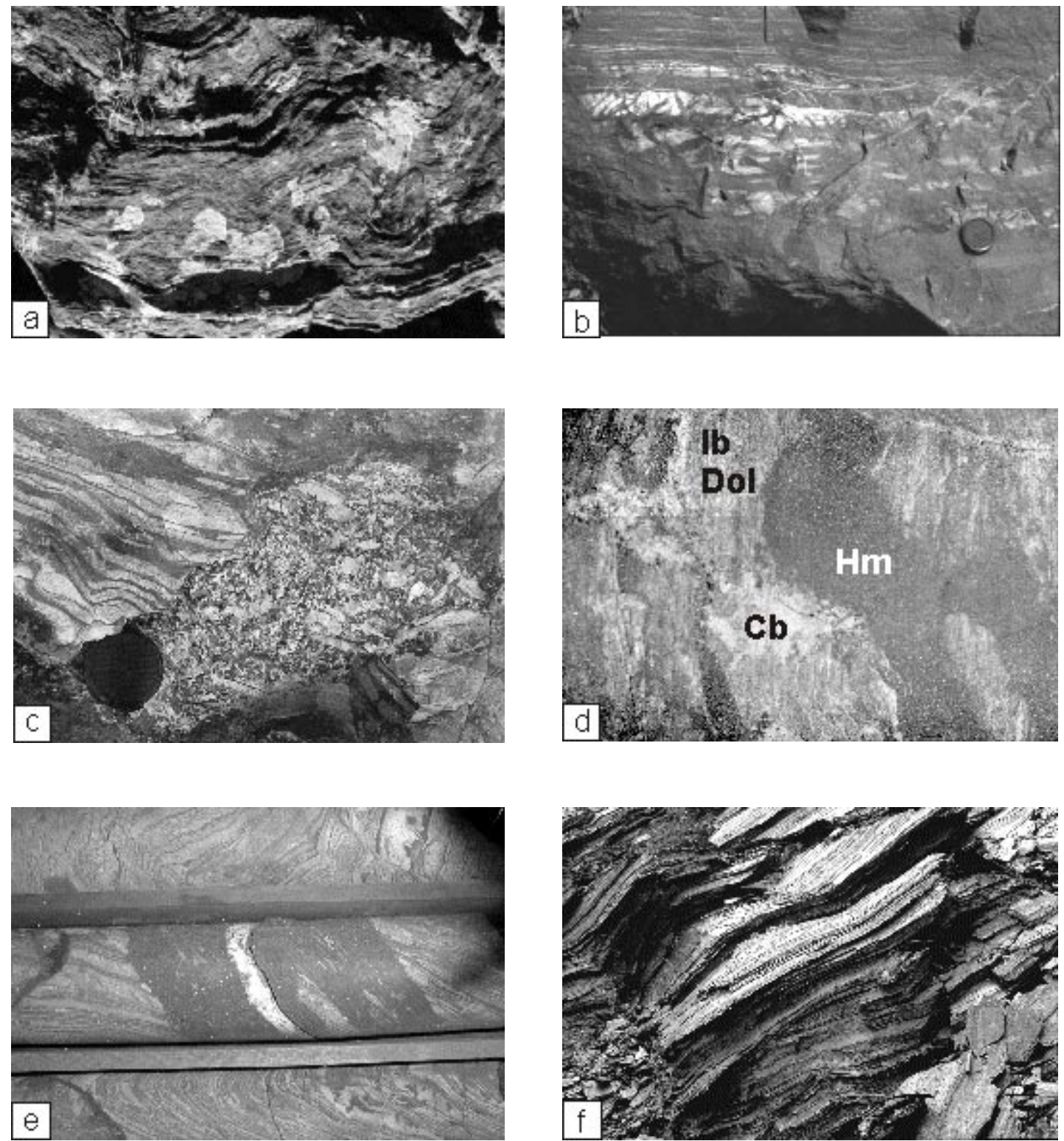

Figura 4: Minérios hipogênicos de alto teor. a. Minério compacto apresentado bandamento e dobramento paralelo concêntrico. O comprimento da foto corresponde a aprox. $1 \mathrm{~m}$. Mina do Pico. b. Substituição parcial das bandas de quartzo por hematita em itabirito. A mineralização propaga-se transversalmente ao bandamento ao longo de fraturas centimétricas. Mina do Pico. c. Brecha por fraturamento hidráulico em quartzo itabirito. O itabirito apresenta estruturas de compactação diferencial. Mina de Casa de Pedra. d. Mineralização de hematita em itabirito dolomítico (Ib Dol). A hematita $(\mathrm{Hm})$ substitui preferencialmente a dolomita ferroana. Veios de carbonato $(\mathrm{Cb})$ cortam também o bandamento da rocha. A altura da foto corresponde à aprox. $5 \mathrm{~cm}$. Mina de Conceição. e. Zona de cisalhamento mineralizada em Fe. A largura dos testemunhos de sondagem é aprox. $7 \mathrm{~cm}$. Mina de Conceição. $f$. Minério xistoso constituído essencialmente de cristais orientados de especularita. Mina de Andrade.

Figure 4: Hypogenic high grade ores. a. Massive ore with folded banding. Folds are of parallel, concentric type. Length of the photo corresponds approx. to $1 \mathrm{~m}$. Pico Mine. b. Itabirite with quartz bands partially substituted by hematite. Mineralization propagates across banding along small fractures. Pico Mine. $c$. Hydraulic breccia in quartz itabirite. Itabirite presents also quartz lenses due to differential compaction. Casa de Pedra Mine. d. Hematite mineralization in dolomitic itabirite ( $\mathrm{Ib} \mathrm{Dol}$ ). Hematite $(\mathrm{Hm})$ substitutes ferroan dolomite. Carbonate veins $(\mathrm{Cb})$ also cut the banding. Height of photo is approx. $5 \mathrm{~cm}$. Conceição Mine. e. Fe mineralization in shear zone. Width of core samples is approx. $7 \mathrm{~cm}$ Conceição Mine. $f$. Schistose specularitic iron ore. Andrade Mine. 

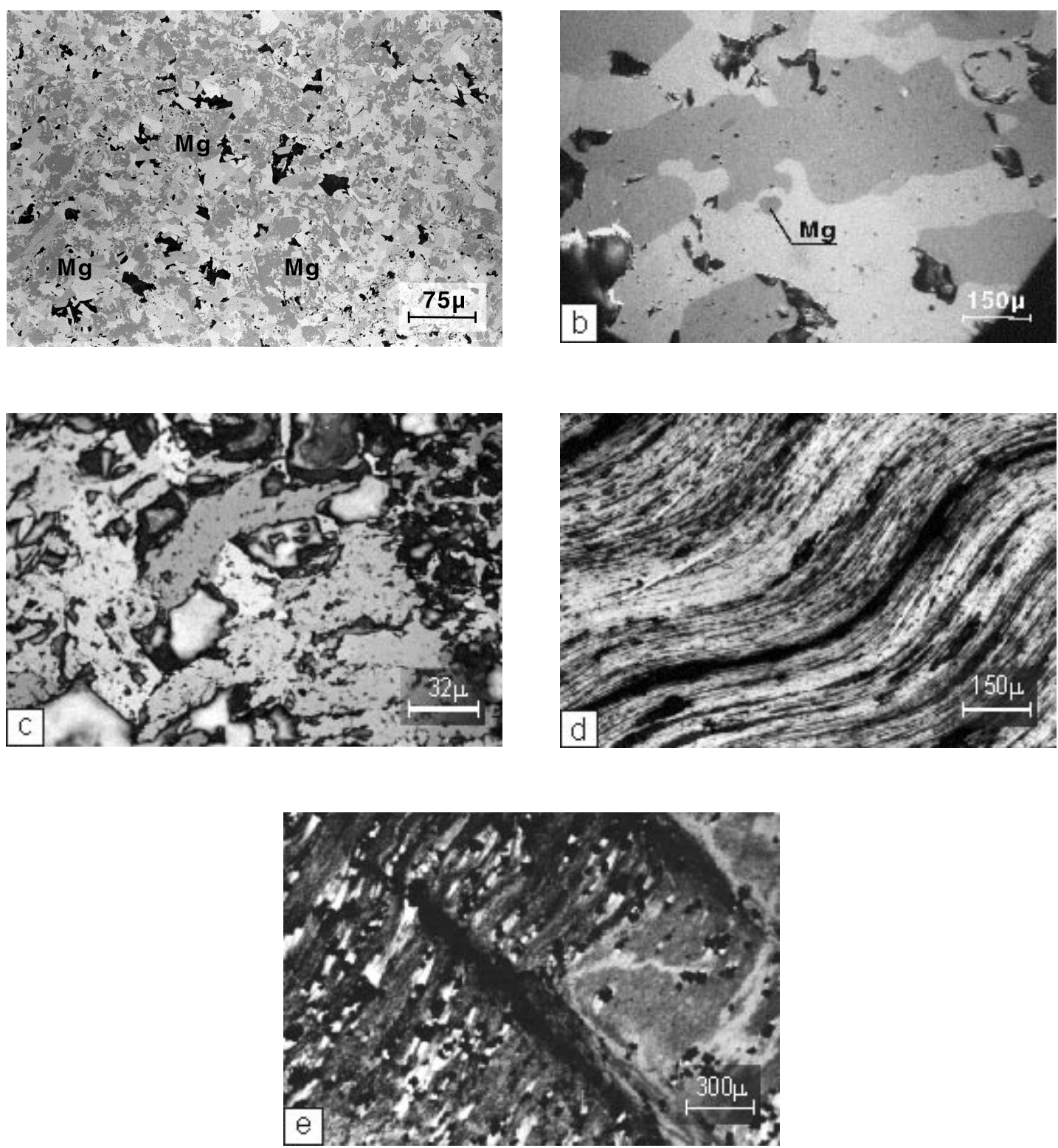

Figura 5: Características microscópicas. a. Magnetita parcialmente martitizada em minério compacto de alto teor. Amostra TF 16, L pol. //. Mina do Córrego do Feijão b. Cristais de hematita em minério totalmente oxidado, apresentando bordas lobadas e embainhadas com relicto de magnetita (Mg) Amostra 57, L pol. //. Mina do Pico do Itabirito. c. Hematita pseudomórfica em anfibólios (?) em minério poroso. Amostra CP17, L pol. parc.X, Mina de Casa de Pedra. d. Finos cristais de especularita em minério xistosos suavemente crenulado. Amostra TF22, Lpol. I/. Mina de Morro Agudo. e. Itabirito anfibolítico com goethita pseudomórfica provavelmente em silicatos (anfibólio e clorita?), magnetita e quartzo. A rocha apresenta foliação paralela ao bandamento de direção NE-SW da foto e clivagem de crenulação que corta a estruturação penetrativa.

Amostra OF 12 Lpol. X. Sinclinal de Ouro Fino.

Figure 5: Microscopic features. a. Partially martitized magnetite in high grade massive ore. Sample TF16, PPL. Córrego do Feijão Mine b. Hematite crystals in completely oxidized ore, with lobate and embayed grain boundaries and magnetite relict (Mg). Sample 57.PPL. Pico do Itabirito Mine. c. Hematite pseudomorphic in amphiboles (?) in ore with high porosity. Sample CP17, part. XPL, Casa de Pedra Mine. d. Fine specularite platelets in slightly crenulated schistose. Sample TF22, PPL. Morro Agudo Mine. e. Amphibolitic itabirite with pseudomorphic goethite in iron silicates (amphibole and chlorite?), magnetite and quartz. Schistosity is parallel to banding in direction NE-SW of the photo and a crenulation clravage transects the penetrative structure. Sample OF 12 XPL. Ouro Fino Syncline. 
ser uma realidade no Quadrilátero Ferrífero, mas de importância restrita. Supor uma origem sin-sedimentar para grandes corpos concordantes de hematita compacta (Harder \& Chamberlin, 1915) situados em domínios de baixa deformação, tais como o do Pico do Itabirito implica na existência, a longo prazo, de condições peculiares devido à ausência de precipitação de $\mathrm{SiO}_{2}$. Essa hipótese entra em conflito com os diversos modelos deposicionais que postulam um equilíbrio estequiométrico entre os componentes ou uma precipitação contínua de sílica em um mar supersaturado nesse composto.

Soluções ascendentes de origem hidrotermal ou hipogênicas derivadas de corpos magmáticos tem sido aceitos por diversos autores desde o início do século XX (Gruner, 1924, 1930, 1937) como responsáveis pelas mineralizações e uma grande variedade de evidências tem sido recentemente apresentadas na literatura baseadas em análise petrográfica, mineragráfica e estudo de inclusões fluidas (Barley et al, 1999, Morey 1999). Um dos indicativos de oxidação associada a um processo hidrotermal na Província de Hamersley são as associações mineralógicas verificadas nas zonas de transição entre formações ferríferas bandadas e os corpos de minério. Enquanto formações ferríferas bandadas naquela região apresentam predominantemente magnetita associada a chert, com algum carbonato (siderita) e silicatos de ferro (stilpnomelana, minnesotaita) o aumento de teor em Fe implica no aumento do grau de oxidação de modo que o minério apresenta mineralogia mais simples com hematita sendo o carbonato predominante dolomita juntamente com hematita.

No sentido de definir a origem dos fluidos mineralizantes para os corpos de hematita, Powell et al. (1999) e Morey (1999) adotam modelos semelhantes para as bacias de Hamersley e Animikie respectivamente. Segundo esses autores fluidos metamórficos seriam contaminados por água meteórica e seu fluxo migratório ocorreria no sentido do cinturão orogênético para o ante-país em função do gradiente de pressão de origem tectônica. Barley et al. (1999) consideram os depósitos de hematita de Hamersley como pós-orogênicos, formados a partir de fluidos mineralizantes gerados em ambiente extensional relacionado à abertura da bacia sobrejacente.

O modelo sedimentar não encontra suporte nas evidências de oxidação e substituição encontradas no minério e na presença de formas irregulares e contatos bruscos apresentados por alguns corpos de minério de alto teor, não somente no QF mas também em regiões indeformadas e de baixíssimo grau metamórfico, como na Serra de Carajás (Tolbert et al. 1971, Beisiegel et al. 1973), no Mesabi Range (Morey, 1999) e em Mt. Tom Price/Hamersley Range (Barley et al. 1999). Brechas hidrotermais por fraturamento hidráulico, mineralizadas, são também encontradas, particularmente nos domínios de baixa deformação (DBD). A existência de inclusões fluidas nos cristais de hematita, particularmente nas palhetas de especularita (Rosière et al 2001b, no prelo), também atesta a sua precipitação a partir de fluidos mineralizantes. No Quadrilátero Ferrífero, o itabirito apresenta grau elevado de oxidação com quartzo e dolomita ferroana como principais minerais de ganga e hematita como óxido mais comum. Magnetita predomina localmente e nas zonas de menor grau de metamorfismo e deformação (principalmente a oeste/ noroeste) embora neste domínio ocorram corpos possantes de minério de alto teor com elevada proporção de magnetita (Córrego do Feijão- Fig. 5, Mutuca, entre outras). Uma questão em aberto, entretanto, é a origem desses fluidos, sua idade e associação ao metamorfismo regional ou intrusões graníticas.

Dorr $(1965,1969)$ e Guild $(1953,1957)$ interpretam os depósitos de minério de ferro do Quadrilátero Ferrífero de uma forma genérica como resultado da mineralização por fluidos metamórficos sin-orogênicos durante a chamada "orogênese pós-Itacolomi” (Dorr, 1969). A idade da mineralização foi postulada por Guild (1957), baseando-se na ausência de seixos de minério hematítico em conglomerados itabiríticos do Grupo Itacolomi e por evidência petrográfica de substituição de grânulos e seixos de quartzo por hematita nessa rocha.

Conglomerados com seixos de itabirito, seixos esses que apresentam dobramento interno, foram considerados por Barbosa (1949) como pertencentes à Formação Santo Antônio, cujo locus tipicus está localizado na Serra do Santo Antônio a SE do Quadrilátero Ferrífero. A posição dessa unidade é bastante controversa na literatura tendo sido considerada por Guild (1957), Dorr (1969) e Glöckner (1981) como Fácies do Grupo Itacolomi mas por Eichler (1969) e Weiss (1990) como pertencente à Formação Cercadinho, do Grupo Piracicaba (Fig. 2), imediatamente sobre as formações ferríferas do Grupo Itabira, separada desta por discordância angular e erosiva (Dorr, 1969). Tais conglomerados encontramse, na maioria das vezes, como escamas de cavalgamentos na porção $\mathrm{S}$ do Quadrilátero Ferrífero (Fig 1A). Intercalados em quartzitos considerados como pertencentes ao Grupo Itacolomi, são encontradas ainda formações ferríferas com componentes aloquímicos constituido de grânulos e mesmo seixos de quartzo (Guild, 1957). A existência de seixos de hematita compacta nesses conglomerados seria uma evidência que permitiria balizar a idade da mineralização mas a sua ausência permite um avanço muito pequeno nesse sentido. A ausência de seixos de minério levou a Guild (1957) deduzir que os processos mineralizantes seriam posteriores ao soerguimento das rochas do Supergrupo Minas, durante a alimentação da bacia molássica Minas/ Itacolomi,. Esse argumento, apesar de importante, é frágil, não satisfazendo como referência de idade da mineralização pois condiciona uma importante conclusão geológica a uma questão fortuita de observação em uma unidade de posição estratigráfica 
controversa (Fácies Santo Antônio). Além disso, existem mais dúvidas que certezas sobre a idade e grau de aloctonia dos metapsamitos enquadrados de forma generalizada como Grupo Itacolomi.

A influência de pelo menos dois ciclos orogênicos após a deposição do Grupo Itabira, o Transamazônico, de idade Paleoproterozóica (2.1-2.0 Ga) e o Brasiliano, de idade Neoproterozóica (0.65-0.50 Ga), provocou uma grande variedade de estruturas e texturas, como já descrito para depósitos individuais (e.g.: Hackspacher 1979, Rosière 1981), e para toda a região por Rosière \& Chemale Jr. (1991), Rosière et. al. (1993, 1998, 2001a, no prelo). Essa complexidade estrutural relacionada à superposição de eventos tectono-termais seguida de uma longa história de processos exógenos levaram a diversos pulsos oxidantes e mineralizantes, provavelmente sob a ação de fluidos de diferentes origens, cuja associação ao desenvolvimento de estruturas tectônicas nas formações ferríferas utilizamos para classificar os minérios e estabelecer modelos genéticos conforme apresentado abaixo.

Três tipos principais de minério podem ser definidos no Quadrilátero Ferrífero:não-tectônicos (hipogênicos ou supergênicos) concordantes ao bandamento e sem aparente condicionamento genético à estrutura tectônica (Fig. 4a), sin-tectônicos (hipogênicos) com claro condicionamento genético à estrutura tectônica (Fig. 4f) e pós-tectônicos (supergênicos) onde a estrutura é um fator auxiliar à extensão da mineralização (facilitando a percolação de fluidos superficiais) mas não há condicionamento genético. A incidência de dois ou três processos provoca a geração de corpos de grandes dimensões e teores elevados e homogêneos como na Mina de Águas Claras (Fig. 1A).

\section{Minérios não-tectônicos}

Corpos de hematita compacta (Fig 4a) ocorrem como lentes de dimensões variáveis com espessura decimétrica a decamétrica apresentando um bandamento definido pela alternância de níveis compactos e porosos de óxidos de ferro com minerais de ganga nos interstícios tais como quartzo e filossilicatos. Grande parte desses corpos são concordantes ocorrendo dentro de níveis filiticos na base da Formação Cauê, intercalados em quartzo itabirito, e frequientemente dentro de corpos gigantescos de minério friável. A sua morfologia tem forte controle do acamamento podendo afinar lateralmente ou passar bruscamente para itabiritos. $\mathrm{O}$ bandamento apresenta geralmente dobras do tipo flexural (Fig. 4a) e de perfil desarmônico com estilo convoluto semelhante a estruturas associadas a slumping e diferente da maioria das dobras encontradas nos itabiritos, que possuem geralmente maior amplitude e denotam maior grau de achatamento. Aparentemente algumas dobras internas dos minérios compactos nuclearam-se enquanto a rocha apresentava-se incipientemente consolidada, provavelmente com características reológicas de um gel (Guild, 1957, Rosière 1981) ou então constituem dobras paralelas aprox. concêntricas, desenvolvidas em condições dúcteis-rúpteis provavelmente anquimetamórficas. Outros minérios compactos apresentam estrutura brechóide, representando provavelmente brechas hidráulicas por alta pressão de fluidos (Fig. 4c). Esses corpos de minério encontram-se igualmente dobrados.

Minérios compactos não tectônicos possuem trama granoblástica (Fig 5b) que pode ser porosa devido a presença de espaços vazios intersticiais ou maciça caracterizada pelo intercrescimento dos cristais de hematita. A orientação incipiente da hematita paralelamente ao bandamento é resultado de efeito de carga ou deslizamento interestratal durante a flambagem das camadas, (Rosière et al. 2001a, no prelo) processo relacionado provavelmente à nucleação dos megassinclinais que são as estruturas mais antigas do Supergrupo Minas no QF, formadas durante o Transamazônico (Chemale Jr. et al., 1994). Esses corpos não apresentam quaisquer indícios de uma clara relação genética com estruturas (traps estruturais e a presença de especularita) a não ser a presença de veios de hematita de dimensões variáveis entre $\mathrm{cm}$ e m. que truncam o bandamento. Essas estruturas atestam, em pequena escala, que o processo de enriquecimento ocorreu em condições dúcteis-rúpteis com fluidos percolando ao longo de microfraturas no sentido vertical, mas se utilizando preferencialmente da anisotropia planar das formações ferríferas para propagar-se no sentido horizontal (Fig. 4b).

Os dados geocronológicos disponíveis indicadores do ciclo Transamazônico como primeiro fluxo térmico sobre as rochas do Supergrupo Minas podem ser combinados à hipótese de Guild (1957) para se estabelecer os limites de idade da geração dos corpos de hematita compacta: Pode-se definir um limite inferior de inferior de $2.4 \mathrm{Ga}$ (idade de deposição do Grupo Itabira - Babinski et al. 1995) e um superior em torno de 2.0 Ga. Deve-se considerar que $2.125 \mathrm{Ga}$, idade do Grupo Sabará e provavelmente do Grupo Itacolomi, corresponde ao paroxismo da tectônica Transmazônica ocorrido muito a Leste do Quadrilátero Ferrífero. O pico térmico determinado no embasamento teria ocorrido no intervalo de 2.04 a 2.06 Ga (Machado et al., 1992, Noce 1995) mas seu real significado tectônico ainda é, pelo menos, alvo de mais discussões, embora Alkmim \& Marshak (1998) o interpretem como associado ao processo de colapso pós orogênico responsável pela ascensão dos domos gnáissicos.

Esses limites são amplos e generosos. As relações de campo aliadas às características petrográficas, mineragráficas e texturais desses minérios indicam que a oxidação da magnetita deve ter ocorrido ao início do metamorfismo ou mesmo durante a diagênese, eventualmente facilitada por cataclase (Rosière et al. 2001a, no prelo), mas claramente muito antes do momento geológico de maior intensidade de deformação já que a estruturação sedimentar/ diagenética encontra-se quase totalmente preservada na maioria dos casos, o que significa que ocorreu lixiviação 
em larga escala dos minerais de ganga e deposição concomitante de hidróxidos/óxidos de ferro sem alteração importante da trama da rocha. Dentro da evolução do ciclo Transamazônico podemos supor as seguintes hipóteses para geração dos fluidos:

- Fluidos associados à geração de corpos graníticos do arco magmático Transamazônico. Os granitóides mais próximos à região do $\mathrm{QF}$ e que podem ser levado em consideração tem idade entre 2.27 e 2.30 (Plutons do Alto Maranhão e Ressaquinha) (Noce 1995, Noce et al. 2000, Noce, este volume) Essa hipótese é bastante plausível e satisfaz as observações acima estipuladas. - Fluidos metamórficos movidos pela diferença de pressão a partir do hinterland da orogênese Transamazônica, possivelmente durante a evolução da megaseqüência II caracterizada pelo Grupo Sabará, cujos efeitos na deformação da megaseqüência I (grupos Caraça, Itabira e Piracicaba) foram tímidos, pelo menos na metade Oeste do Quadrilátero Ferrífero sem promover deformação interna importante nas rochas e o desenvolvimento de xistosidade penetrativa com alteração da trama sedimentar e diagenética (Chemale Jr. et al, 1994, Alkmim \& Marshak, 1998). Dessa forma o impulso motor do fluxo dos fluidos vindo de leste iniciou-se anteriormente a $2.125 \mathrm{Ga}$, que se postula como idade do auge da deformação, atingindo as formações ferríferas talvez a 2.2Ga (?).

- Fluidos associados à extensão da bacia durante a ascensão dos domos gnáissicos. Essa hipótese é bastante controversa em virtude da polêmica em torno da idade e processos que levaram a formação das estruturas em domo e bacia (comparar modelos de Chemale Jr et al. 1994, Alkmim \& Marshak, 1998 e Hippertt \& Davis, 2000).

Corpos de minério compacto constituído essencialmente de kenomagnetita apresentando baixo grau de martitização são encontrados no DBD, a oeste do Quadrilátero Ferrífero. Estes representam um problema adicional para ser esclarecido por processos epigenéticos já que não sofreram a oxidação normalmente apresentada pelos corpos mineralizados. Pode-se supor que tais corpos tenham origem singenética como suposto por Harder \& Chamberlin (1915) e Rosière (1981) em função de sua ocorrência restrita.

\section{Minérios sintectônicos}

Evidência da atuação de processos sin-tectônicos são mais claramente observados nos domínios de maior deformação do Quadrilátero Ferrífero (DAD), particularmente na sua extremidade Leste e Nordeste onde ocorrem concentrações anômalas associadas a zonas de cisalhamento (Fig 4e) que truncam o bandamento (Rosière et al. 1997). A existência desses corpos indicam a importância metalogenética de fluidos hidrotermais sintectônicos que podem atuar de duas formas:

- pela lixiviação de minerais de ganga, como o quartzo, dentro do mecanismo de dissolução por pressão - pela mobilização de $\mathrm{Fe}^{2+}$ da estrutura da kenomagnetita e sua precipitação na forma oxidada como especularita em sítios extensionais (Lagoeiro, 1998)

Através desse processo não há necessidade de condições especiais de substituição para se preservar a estruturação da rocha. Ele produz minérios de teores variáveis até corpos xistosos puramente hematíticos e a perda de volume e estrutura seria compensada pela intensa deformação e recristalização com o desenvolvimento de minérios especularíticos.

Guba (1982), baseada em observação no depósito de Morro Agudo, próximo a João Monlevade (NE do Quadrilátero Ferrífero) postulou um modelo baseado no desenvolvimento de jazidas do tipo saddle reef com a concentração de Fe remobilizado em zonas de charneira de dobras, mas não se tem encontrado evidência da ampla aplicabilidade desse modelo.

Outros corpos especularíticos são produto da deformação de corpos compacto de mineralização não tectônica. Isso pode ser constatado pela presença de pods e boudins de hematita compacta dentro de minério ou itabirito xistoso.

A idade e origem dos fluidos responsáveis pela mineralização dos corpos sintectônicos apresenta-se como um problema ainda mais complexo pois podem ter sido gerados durante a deformação associada ao evento Transamazônico ou ao ciclo Brasiliano. A leste do Quadrilátero Ferrífero no domínio de alta deformação, onde predominam minérios tectônicos ocorrem os granitos do tipo Borrachudos que podem ser levados em consideração na procura de fontes para os fluidos mineralizantes pois se cristalizaram a $1.67 \mathrm{Ga}$ e foram deformados a $1.35 \mathrm{Ga}$ (Chemale Jr. et al, 1997). Dados de zircão e monazita de Schrank \& Machado (1996 a, b) e uma isócrona $\mathrm{Pb}-\mathrm{Pb}$ de anfibólio (Noce 1995) indicam um evento hidrotermal importante a 1.8 Ga (Noce, neste volume). Para, entretanto, abordar esse problema de forma conseqüente é necessário ainda um estudo comparativo entre as características dos fluidos dos minérios hematíticos com outras mineralizações e um rigoroso controle estrutural.

\section{Minérios pós-tectônicos (supergênicos)}

Modelos envolvendo águas superficiais tem sido extensivamente utilizados (Leith 1903; Van Hise \& Leith 1911; Leith et al. 1935) mas que não podem ser aplicados de forma simples e direta para esclarecer a origem dos corpos compactos. Morris (1980, 1993) definiu um modelo supergênico pré-metamórfico com lixiviação de quartzo e precipitação concomitante de óxidos em superfície relacionado a um longo período de exumação. Apesar de ter encontrado ampla aceitação, o modelo de Morris encontra fortes argumentos contrários ao ser confrontado com evidências geológicas tais como a pouca eficiência de fluidos intempéricos na produção de corpos gigantescos em grande profundidades, a necessidade do confinamento das formações ferríferas como aqüífero entre unidades impermeáveis e finalmente a necessidade de um metamorfismo de carga a uma profundidade de, no mínimo 5Km, para o qual não há evidência em diversos 
casos como argumentado por Powell et al. (1999)

No Quadrilátero Ferrífero, em virtude das características climáticas da região, o intemperismo tem uma importância fundamental na geração dos corpos lavráveis de minério de ferro de alto teor através da lixiviação de $\mathrm{SiO}_{2}$ (Dorr 1964) e principalmente dos carbonatos por águas superficiais. Águas meteóricas nas condições climáticas locais podem, segundo Eichler (1967), dissolver anualmente $4,55 \mathrm{~g} \mathrm{SiO}_{2} / \mathrm{m}^{2} \mathrm{de}$ superfície considerando precipitação anual de chuva de $600 \mathrm{~mm}$. O processo de intemperismo próximo à superfície é responsável também pela oxidação e hidratação da magnetita e, em menor proporção, da hematita, formando uma crosta laterítica (canga). A profundidade dessa crosta varia de alguns metros até dezenas de metros e protege as formações ferríferas subjacentes da oxidação e hidratação permitindo maior efetividade da lixiviação da $\mathrm{SiO}_{2}$. Eichler (1967) e Chemale Jr. et al. (1987) apresentaram perfis de intemperismo idealizados nos itabiritos do QF apresentando da base para o topo: Itabirito duro $\rightarrow$ itabirito friável $\rightarrow$ itabirito brando $\rightarrow$ hematita friável $\rightarrow$ canga. Segundo Eichler (1967) o processo de enriquecimento supergênico deve ter se iniciado no ciclo de erosão Sulamericano (King, 1956) aumentando o teor e volume de rocha mineralizada com a maturidade do perfil e diminuição do nível do lençol freático (Barbosa 1987, Varajão 1991, Gorceix 1884) auxiliado pela estruturação das formações ferríferas e pela ação de atividade tectônica recente (Brajnikov 1947; Saadi et al. 1992). Estruturas planares e lineares permitem uma percolação mais efetiva induzindo um enriquecimento mais rápido.

Os principais produtos de intemperismo dos itabiritos e suas características estão apresentados na tabela 3. Itabiritos "chapinha" (Fig. 6a) são produtos do intemperismo onde as bandas são parcialmente preservadas após a lixiviação e remoção mecânica dos minerais de ganga. A estruturação do bandamento é particularmente resistente ao intemperismo se houver cimentação por limonita e a presença de especularita cujas plaquetas são claramente resistentes à hidratação favorecem a desagregação em placas (chapinhas). Esse minério pode ser encontrado in situ ou constituindo depósito de concentração residual.

Um tipo de minério particularmente importante do ponto de vista econômico é o denominado comumente de "rolado", produto da erosão de corpos de hematita compacta, constituídos por blocos de dimensões variadas de minério compacto, concentrados em ravinas e vales adjacentes aos depósitos metamórficos e cimentados por hidróxidos de ferro.

Nos produtos de alteração ocorrem freqüentemente cristais "negativos" de magnetita martitizada, juntamente com goethita e lepidocrocita. Nesses cristais "negativos", os relictos de magnetita foram hidratados, formando hidróxidos de ferro que são lixiviados, permanecendo hematita sustentando a forma original de octaedros e tetraedros enquanto os hidróxidos são reprecipitados constituindo cimento limonítico. Os itabiritos dolomíticos são particularmente importantes como protominérios. Os grandes corpos de minério intempérico de alto teor são produto de sua alteração (Fig. 6b), através do enriquecimento residual do ferro por lixiviação do carbonato deixando atrás de si uma estruturação cárstica com cavernas e relictos de itabirito dolomítico isolados e fazendo contato brusco com o minério.

Os minérios intempéricos do Quadrilátero Ferrífero são, além de friáveis, em sua maioria hematíticos, diferentemente dos minérios duros de composição predominantemente goethítica da província de Hamersley. No QF goethita ocorre como cimento e contaminante em depósitos supergênicos provenientes de itabiritos magnetíticos/martíticos no DBD. A leste da região, no DAD, minérios supergênicos são principalmente itabiritos friáveis xistosos com predominância de especularita.

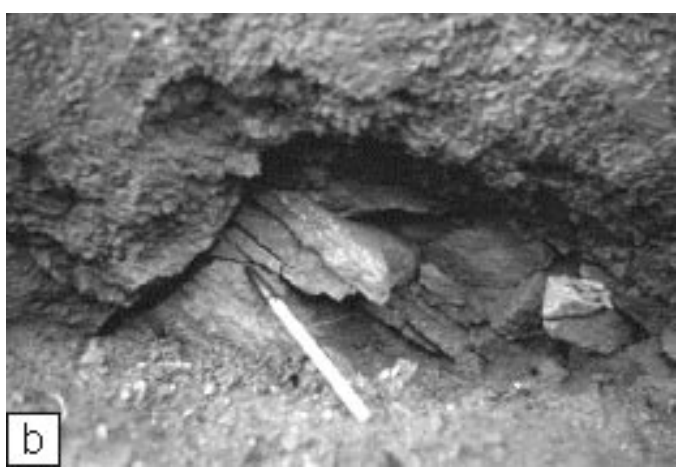

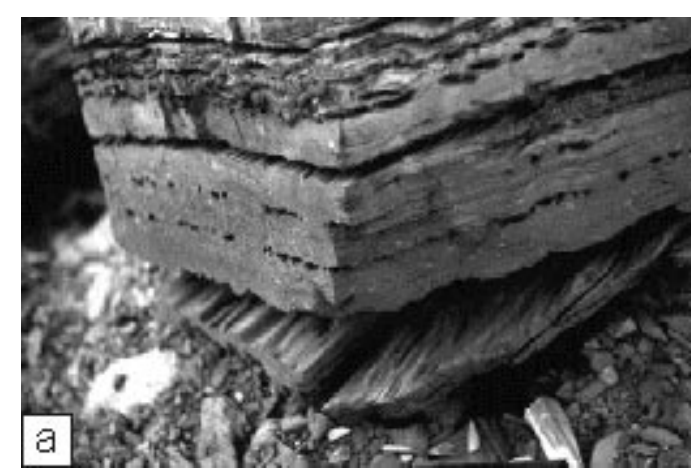

Figura 6: Produtos de intemperismo de itabiritos a. Quartzo itabirito intemperizado com desenvolvimento incipiente de "chapinhas". A parte do meio do bloco encontra-se cimentada por goethita/limonita. A aresta esquerda do bloco possui aproximadamente $1 m$ de comprimento. Serra do Itabirito. $b$. Minério friável com relicto de itabirito dolomítico em contato brusco. Mina de Águas Claras.

Figure 6: Weathering products of itabirites a. Weathered quartz-itabirite with beginning desegregation of "chapinha"-plates. The central part of the block is cemented by goethite/limonite. The edge of the block on the left is approx. Im long. Serra do Itabirito. $b$. Friable ore in sharp contact with rests of dolomitic itabirite. Águas Claras Mine. 


\begin{tabular}{|c|c|}
\hline \begin{tabular}{c|} 
TIPOS \\
INTEMPERIZADOS \\
\end{tabular} & CARACTERÍSTICAS PRINCIPAIS \\
\hline Canga e rolado & $\begin{array}{l}\text { Placas e blocos de hematita em cimento limonítico/goethítico. Magnetita, hematita, } \\
\text { diferentes hidróxidos e óxidos de Fe e Mn e fosfatos secundários estão presentes. } \\
\text { Relictos de bandamento primário ou tectônico pode ser distinguido eventualmente } \\
\text { (canga estruturada). }\end{array}$ \\
\hline $\begin{array}{l}\text { Minério e itabirito } \\
\text { friável }\end{array}$ & $\begin{array}{l}\text { Desintegra-se em placas. Bandamento e xistosidade ainda é reconhecível. Goethita e } \\
\text { limonita estão presentes nas variedades magnetíticos. Quartzo friável ocorre em } \\
\text { diferentes proporções. Bandas dolomíticas alteram em material argiloso, higroscópico } \\
\text { de cor ocre a avermelhada. Pseudomorfos de limonita/goethita em anfibólios e clorita }\end{array}$ \\
\hline Chapinha & $\begin{array}{l}\text { Itabirito semi-friável bandado com clivagem conspícua paralela ao bandamento. O } \\
\text { bandamento desintegra e, placas de espessura milimétrica. Quartzo extensivamente } \\
\text { lixiviado }\end{array}$ \\
\hline
\end{tabular}

\section{Tabela 3: Características principais dos produtos de intemperismo.}

Table 3: Main features of the alteration products.

\section{AGRADECIMENTOS}

Os autores agradecem às agências financiadoras CNPq, CAPES e FINEP(PADCT) e ao DAAD pelo apoio ao estudo das formações ferríferas, principalmente ao primeiro autor. Às empresas de mineração CVRD, MBR, SAMITRI, SAMARCO, FERTECO, Belgo Mineira, MSG, e CSN expressamos igualmente nossos agradecimentos pelo irrestrito acesso às minas e inestimável apoio logístico. Em particular agradecemos aos colegas e amigos A. Januzzi da Belgo-Mineira, M. Rossi, E. L. Albanez, M. Häusler e L. Vanucci da FERTECO; C. A. Spier, D. Tamantini de Souza, E. Zanetti Fernandes e O. Tessari da MBR, K. Kaneko da SAMITRI, A. G. da Costa da SAMARCO e em especial a M. L. Vidigal Guimarães, E. M. Resende de Souza, E. Caldeira Leite, e R. A. Custódio de Souza da CVRD, por dividir generosamente informações e observações valiosas, fruto de sua meticulosidade, sagacidade e competência que enriqueceram sobremaneira o presente trabalho. Agradecemos finalmente a. H. Quade, C. M. Noce, L. Lobato, S. Guedes, M. Barley, N. Beukes e B. Simonson, pelas valiosas discussões, a F. J. Baars pela revisão do texto e a R. D. Costa pela infinita paciência na editoração do trabalho.

\section{REFERÊNCIAS BIBLIOGRÁFICAS}

Alkmim, F. F. \& Marshak, S. 1998. Transamazonian Orogeny in the Southern São Francisco Craton Region, Minas Gerais, Brazil: evidence for Paleoproterozoic collision and collapse in the Quadrilátero Ferrífero. Precambrian Research, 90: 29 - 58.

Almeida, F. F. M. 1977. O Craton de São Francisco. Rev. Bras. Geociências, 7 (4): 349 - 364.

Babinski, M., Chemale Jr., F. \& Van Schmus, W. R. 1995. The Pb/ $\mathrm{Pb}$ age of Minas Supergroup carbonate rocks, Quadrilátero Ferrifero, Brazil, and its implications to the correlation with BIFs from South Africa and Australia. Precambrian Research, 72: $235-245$

Baars, F. J. \& Rosière, C. A., 1997. Geological map of the Quadrilátero Ferrífero. In Baars, F. J. The São Francisco Craton. In De Wit, M. J., Ashwal, L. A. (eds.). Greenstone Belts, Oxford Monographs on Geology and Geophysics Series, Oxford University Press, 529-557.

Barbosa, G.V. 1980. Superfícies de erosão no Quadrilátero Ferrífero. Rev. Bras. Geociências, 10(1): 89-101.

Barbosa, O. 1949. Contribuição à geologia do centro de Minas Gerais. Mineração e Metalurgia, XIV (79): 3 - 19.
Barley, M. E., Pickard, A. L., Hagemann, S. G. \& Folkert, S. L. 1999. Hydrothermal origin for the 2 billion year old Mount Tom Price giant iron ore deposit, Hamersley Province, Western Australia. Min. Dep., 34: 784 - 789.

Brajnikov, B. 1947. Essai sur la tectonique de la région à l' est de Belo Horizonte, Minas Gerais, Brésil. Bull. Soc. Géol. France, 17: 321-335.

Beisiegel, V. R., Bernardelli, A.L., Drumond, N. F., Ruff, A.W. \& Tremaine, J. W. 1973. Geologia e Recursos Minerais da Serra dos Carajás. Rev. Bras. de Geociências, 3: 215-242

Beukes, N. J. 1980. Suggestions toward a classification of and nomenclature for iron-formation. Trans. Geol. Soc. S. Afr.. 83: 285 - 290.

Beukes N. J. 1986. The Transvaal Sequence in Griqualand West, In Anhaeusser, C. R. \& Maske, S. (eds) Mineral Deposits of Southern Africa. Vol I, Johannesburg, Geol. Soc. S. Afr., $817-828$

Button A. 1986. The Transvaal Sub-Basin of the Transvaal Sequence, In Anhaeusser, C. R. \& Maske, S. (eds) Mineral Deposits of Southern Africa. Vol I, Johannesburg, Geol. Soc. S. Afr., $811-817$.

Chemale, F. Jr., Quade, H. \& Santana, F. C. 1987. Economic and structural geology of the Itabira Iron District, Minas Gerais, Brazil. Zbl. Geol. Paläontol., VI (7/8): 743 - 752.

Chemale, F. Jr., Rosière, C. A. \& Endo, I. 1994. The tectonic evolution of the Quadrilátero Ferrífero, Minas Gerais, Brazil. Precambrian Research, 65: 25 - 54

Chemale, F. Jr., Quade, H. \& van Schmus, W. R. 1997. Petrography, geochemistry and geochronology of the Borrachudo and Santa Barbara metagranites, Quadrilátero Ferrífero, Brazil. Zbl. Geol. Paläont., I (36): 739-750.

Dorr, J. V. N. $2^{\text {nd }} .1964$. Supergene iron ores of Minas Gerais, Brazil. Econ. Geol., 59 (7): 1203 - 1240.

Dorr, J. V. N. $2^{\text {nd }} .1965$. Nature and origin of the high grade hematite ores of Minas Gerais, Brazil. Econ. Geol., 60 (1): 1-46.

Dorr, J. V. N. $2^{\text {nd }}$. 1969. Physiographic, stratigraphic and structural development of the Quadrilátero Ferrífero, Minas Gerais. U. S. Geol. Surv. Prof. Pap., 641-A: 110p.

Eschwege, W. L. v. 1833. Pluto Brasiliensis. Berlin, Verlag G. Reimer.

Eichler, J. 1967. Das physikalische Millieu bei der Verwitterung von Itabiriten in Minas Gerais/Brasilien. Chemie der Erde, 26 (2): $119-132$.

Galbiatti, H. 1999. Natureza e controle estrutural da mineralização aurífera (jacutingas) na Mina Cauê, Itabira, MG. Escola de Minas, Universidade Federal de Ouro Preto, Ouro Preto, Diss. Mestrado, 150p.

Glöckner, K. H. 1981. Lithostratigraphie, Sedimentologie Tektonik und Metamorphose der proterozoischen Itacolomie - Serie bei Ouro Preto, Minas Gerais, Brasilien. Clausthaler Geowissenschaftliche Dissertationen, 10: 221p.

Gorceix, H. 1884. Bacias terciárias d' água doce nos arredores de Ouro Preto (Gandarela \& Fonseca), Minas Gerais, Brasil. Anais Esc. Min. Ouro Preto, 3:75-92.

Gruner, J. W. 1924. Contributions to the geology of the Mesabi Range, with special reference to the magnetites of the iron bearing formation west of Mesaba: Minnesota. Geological Survey Bulletin, 19, 71p. 
Gruner, J. W. 1930. Hydrothermal oxidation and leaching experiments: their bearing on the origin of Lake Superior hematite - limonite ores. Econ. Geol., 25, parte I: 697 - 719, parte II: $837-867$.

Gruner, J. W. 1937. Hydrothermal leaching of iron ores of the Lake Superior type - a modified theory. Econ. Geol. 32: 121 - 130.

Guild, P. W. 1953. Iron deposits of the Congonhas District, Minas Gerais, Brazil. Econ. Geol., 48: 639 - 676.

Guild, P. W., 1957 Geology and mineral resources of the Congonhas District, Minas Gerais, Brazil. U. S. Geol. Surv. Prof. Pap. 290: $90 \mathrm{p}$.

Guba, I. 1982. Tektonik, Texturen und Mineralogie der präkambrischen Eisenerze und Nebengesteinsserien der Lagerstätte Morro Agudo im NE des Quadrilátero Ferrífero/ Minas Gerais, Brasilien. Geologisches Institut, T. U. Clausthal, Clausthal, Alemanha. Tese de Doutorado, 342p.

Hackspacher, P. C. 1979. Strukturelle und texturelle Untersuchungen zur internen Deformation des Eisenreicherzkörpers der Grube "Aguas Claras" bei Belo Horizonte, Minas Gerais Brasilien. Clausthaler. Geol. Abh., 34: 164p.

Harder, E. C. \& Chamberlin, R. T. 1915. The geology of Central Minas Gerais, J. Geol. 23 (445): 341 - 424.

Herz, N. 1978 Metamorphic rocks of the Quadrilátero Ferrífero, Minas Gerais, Brazil. U. S. Geol. Surv. Prof. Pap., 641C: 78p.

Hippertt, J. F. \& Davis, 2000. Dome emplacement and formation of kilometer-scale synclines in a granite - greenstone terrain (Quadrilátero Ferrífero, southeastern Brazil). Precambrian Research 102: 99 - 121.

Hoeffs, J., Müller, G. \& Schuster, A. 1982. Polymetamorphic relations in iron ores from the Iron Quadrangle, Brazil: the correlation of oxigen isotope variations with deformation history. Contrib. Mineral. Petrol., 79: 241 - 251.

Hoffman, P. F. 1987 Early Proterozoic foredeeps, foredeep magmatism, and Superior - Type Iron Formations of the Canadian Shield. In Kröner, A., (ed.) Proterozoic Lithospheric evolution: AGU Geodynamics Series, 17: 85 - 98.

James, H. L. 1954. Sedimentary facies of iron formation. Econ. Geol., 49 (3): 235 - 293.

King, L. 1956. Geomorfologia do Brasil Oriental. Rev. Bras. Geog., 18(2):147-266.

Kullerud, G., Donnay, G. \& Donnay, J. D. H. 1969. Omission solid solution in magnetite: Kenotetrahedral magnetite. Zeitschrift für Kristallographie 128: 1-17.

Lagoeiro, L. E., 1998. Transformation of magnetite to hematite and its influence on the dissolution of iron oxide minerals. Journal of Metamorphic Geology, 16: 415-423.

Leith, C. K. 1903, The Mesabi Iron-bearing District of Minnesota. U. S. Geological Survey Monographs 43: 316p.

Leith, C. K., Lund, R. J. \& Leith, A. 1935. Pre-Cambrian Rocks of the Lake superior Region, U. S. Geologica Survey Prof. Paper 84: 34 p.

Machado, N., Noce, C. M., Ladeira, E. A. \& Belo de Oliveira, O. A. 1992. U-Pb Geochronology of Archean magmatism and Proterozoic metamorphism in the Quadrilatero Ferrífero, southern São Francisco Craton, Brazil. Geological Society of America Bulletin, 104: 1221-1227

Machado, N. \& Carneiro, M. A., 1992. U-Pb evidence of the late Archean tectono-thermal activity in the southern São Francisco shield, Brazil. Canadian Journal of Earth Sciences, 29: 2341-2346

Machado, N., Schrank, A., Noce, C. M. \& Gauthier, G., 1996. Ages of detrital zircon from Archean-Paleoproterozoic sequences. Implications for greenstone belt setting and evolution of a Transamazonian foreland basin in Quadrilátero Ferrífero, southeast Brazil: Evidence from zircon ages by laser ablation ICPMS. Earth and Planetary Science Letters, 141: 259 - 276.

Marshak, S. \& Alkmim, F. F. 1989. Proterozoic extension/ contraction tectonics of the southern São Francisco Craton and adjacent regions, Minas Gerais, Brazil: a kinematic model relating Quadrilátero Ferrífero, São Francisco Basin and Cordilheira do Espinhaço. Tectonics, 8 (3): 555 - 571.

Marshak, S., Alkmim, F. F. \& Jordt-Evangelista, H. 1992. Proterozoic crustal extension and generation of dome and keel structure in the Archean granite - greenstone terrane. Nature, 357: 491 - 493.

Morey, G. B. 1983. Animikie Basin, Lake Superior region, U.S.A., In Trendall, A. F. \& Morris R. C. (eds.) Iron-formation: Facts and Problems, Amsterdam, Elsevier, 13-68.
Morey, G. B. 1999. High - Grade Iron Ore Deposits of the Mesabi Range, Minnesota - Product of a Continental-Scale Proterozoic Ground-Water Flow System, Econ. Geol. 94: 133 - 142.

Morris, R. C. 1980. Magnetite - hematite relations in the banded iron formations in the Hamersley Iron Province of Western Australia. Econ. Geol., 75: $184-209$.

Morris, R. C. 1993. Genetic modeling for banded iron formation of the Hamersley Group, Pilbara Craton, Western Australia. Precambrian Research, 60: $243-286$.

Noce, C. M. 1995. Geocronologia dos eventos magmáticos, sedimentares e metamórficos na região do Quadrilátero Ferrífero, Minas Gerais. Inst. de Geociências, Universidade de São Paulo, São Paulo, 128 p.

Noce, C. M. 2000. Geochronology of the Quadrilátero Ferrífero - a review. Geonomos, este volume.

Noce, C. M., Teixeira, W., Quéméneur, J. J. G., Martins, V. T. S. \& Bolzachini, E. 2000, Isotopic signatures of paleoproterozoic granitoids from the southern São Francisco Craton and implications for the evolution of the Transmazonian Orogeny. Journal of S. American Earth Sciences 13: 225 - 239.

Olivo, G. R., Gauthier, M., Bardoux, Leão de Sá, E., Fonseca, J. T. F. \& Carbonari, F. 1995. Palladium-bearing gold deposit hosted by Proterozoic Lake Superior - type iron formation at the Cauê Iron mine, Itabira District, Southern São Francisco Craton, Brazil: geologic and structural control. Econ. Geol. 90: 118 - 134.

Pires, F. R. M. 1995. Textural and mineralogical variations during metamorphism of the Proterozoic Itabira Iron Formation in the Quadrilátero Ferrífero, Minas Gerais, Brazil. An. Acad. Brasileira de Ciências, 67(1): 77-105

Powell, C. McA., Oliver, N. H. S., Li, Z. X. \& Martin, D. McB. 1999. Synorogenic hydrothermal origin for hamersley giant iron oxide ore bodies, Geology, 27: 175 - 178.

Renger, F.E., Noce, C. M., Romano, A. W. \& Machado, N. 1994. Evolução sedimentar do Supergrupo Minas: 500Ma. de registro geológico no Quadrilátero Ferrífero, Minas Gerais, Brasil. Geonomos, 2 (1): 1-11.

Romano, A. W. 1989. Évolution tectonique de la région nord-ouest du Quadrilatère Ferrifère - Minas Gerais - Brésil (Géochronologie du socle - Aspects geochimiques et pétrographiques des Supergroupes Rio das Velhas et Minas). Universidade de Nacy, Nancy, França, Tese de Doutorado, 259p.

Rosière, C. A. 1981. Strukturelle und Texturelle Untersuchungen in der Eisenerzlagerstaette "Pico de Itabira" bei Itabirito, Minas Gerais, Brasilien. Clausthaler Geowissenschaftliche Dissertationen, 9: 302p.

Rosière, C. A. \& Chemale, F. Jr., 1991. Textural and structural aspects of iron ores from Iron Quadrangle, Brazil. In Pagel, M. \& Leroy, J. L. (eds.). Source, Transport and Deposition of Metals, Amsterdam, Balkema, 485 - 488.

Rosière, C. A., Chemale, F. Jr. \& Guimarães, M.L.V. 1993. Um modelo para a evolução microestrutural dos minérios de ferro do Quadrilátero Ferrífero. Parte I - estruturas e recristalização. Geonomos, 1(1): 65-84

Rosière, C. A., Chemale, F. Jr., Vanucci, L. C., Guimarães, M. L. V., Santana, F. C. \& Carmo Jr. J. A. 1997. A estrutura do Sinclinório de Itabira e a tectônica transcorrente do NE do Quadrilátero Ferrífero. In: Simpósio Nacional de Estudos Tectônicos, 6, Pirenópolis, 225 - 226.

Rosière, C.A., Quade, H., Siemes, H. \& Chemale, F. Jr., 1998. Fabric, texture and anisotropy of magnetic susceptibility in high-grade iron ores from the Quadrilátero Ferrífero, Minas Gerais, Brazil. Materials Science Forum, 273-275: 693-700.

Rosière, C. A., Siemes, H. Quade, H., Brokmeier, H.-G. \& Jansen, E. M. 2001a. Microstructures, textures and deformation mechanisms in hematite. Journal of Structural Geology, 23 (8) no prelo.

Rosière, C. A., Rios, F. J. \& Siemes, H. 2001b. Deslizamento intracristalino no plano basal da hematita por enfraquecimento hidrolítico. In: Simpósio Nacional de Estudos Tectônicos, 8, Recife, Resumos, no prelo.

Saadi, A., Sgarbi, G.N.C. \& Rosière, C.A. 1992. A Bacia do Gongo Soco; nova bacia terciária no Quadrilátero Ferrífero: controle cárstico e/ou tectônico. In: SBG Congr. Bras. Geol., 37, São Paulo, Anais, 1: 600-601.

Schrank, A. \& Machado, N. 1996a. Idades U-Pb em monazitas e zircões das minas de Morro Velho e Passagem de Mariana Quadrilátero Ferrífero (MG). In: SBG Congr. Bras. Geol., 39, Natal, Anais, 6: 470 -472. 
Schrank, A. \& Machado, N. 1996b. Idades U-Pb em monazitas e zircões do distrito aurífero de Caeté, da Mina de Cuiabá e do Depósito de Carrapato - Quadrilátero Ferrífero (MG In: SBG Congr. Bras. Geol., 39, Natal, Anais, 6: 473 -475.

Simonson, B., 1987. Early silica cementation and subsequent diagenesis in arenites from four early proterozoic iron formations of North America. Jour. Sed. Petr., 57 (3): 494 - 511.

Tolbert, G. E., Tremaine, J. W., Melcher, G. C. \& Gomes, C. B. 1971. The recently discovered Serra dos Carajás Iron deposits, Northern Brazil. Econ. Geol., 66: 985-994

Trendall, A. F. 1973. Varve cycles in the Weeli Wolli Formation of the precambrian Hamersley Group, Western Australia. Econ. Geol., 68 (7): 1089 - 1097.

Trendall, A. F. 1983. The Hamersley Basin. In Trendall, A. F. \& Morris R. C. (eds.) Iron-formation: Facts and Problems, Amsterdam, Elsevier, 69-129.

Trendall, A. F. \& Blockley, J. G. 1970. The iron formations of the Hamersley Group, Western Australia, with special reference to the associated crocedolite. Western Austr. Surv. Bull., 119: 353p.
Trendall, A. F., Compston, W., Williams, I. S., Armstrong, R. A., Arndt. N. T., McNaughton, N. J., Nelson, D. R., Beukes, N. J., Laeter, J. R., Retief, E. A. \& Thorne, A. M. 1990. Precise zircon $\mathrm{U}$ - Pb chronological comparison of the Kapvaal and Pilbara Cratons between about 3.1 and $2.4 \mathrm{Ga}$. In: Int. Archean Symp, Perth, Abstracts, 3: $81-83$.

Van Hise, C, R, \& Leith, C. K. 1911. The geology of the Lake Superior Region. U. S. Geological Survey Monograph, 70: 641p. Varajão, C.A.C. 1991. A questão da correlação das superfícies de erosão do Quadrilátero Ferrífero, Minas Gerais. Rev. Bras. Geociências, 21(2):138-145.

Weiss, H. 1990. Sedimentologische, lithostratigraphische und tektonische Untersuchungen im Bereich der Santo AntônioFazies, SW Rand des Eisernen Vierecks, Minas Gerais, Brasilien. Geologisches Institut, T. U. Clausthal, Clausthal, Alemanha. Tese de Doutorado, 160p. 